\title{
Actualization of Data Concerning Surface Flowing Waters, Based on INSPIRE Directive Requirements ${ }^{* *}$
}

\section{Introduction}

In June 2010, the Law on infrastructure for spatial information [14] came into force in Poland. It resulted in a transposition of the INSPIRE Directive into the national law, changing a number of the existing legal acts in Poland. One of them was the geodetic and cartographic law [1]. This modification has led to the greatest revolution in the surveying performance since 1989 when the current regulations were introduced. The topic was widely discussed and commented [4,7-10]. As a result of the ongoing changes, new standards for land surveying are created. Both those which were already created and adopted by the Polish legislators and those in the project phase, have had a large impact on the collecting and processing of information about the elements of space so far. This is of course closely associated with the changes that must occur in the currently accepted principles of surveying and mapping works.

The new legislation shall relate to, among others, a topographic database of the detail that ensures the creation of standard cartographic documents in scales of 1:500-1:5000 (BDOT500). It shall include the spatial location of the objects included in it, and their characteristics. One element of the database will be surface water, whose geometry will be related to the geometry of the database objects of the real estate cadastre, and thus to the objects of the already existing database of the state register of the boundaries and areas of territorial division units.

The databases established as mandatory under the geodetic and cartographic law must be verified on a regular basis. Since water is one of the most unpredictable elements, it can cause the most problems in the works related to updating

* AGH University of Science and Technology, Faculty of Mining Surveying and Environmental Engineering, Department of Geomatics, Krakow, Poland

** This work is financed from science funds realized at AGH University of Science and Technology, allocated for the year 2012, no. 11.11.150.006 
these databases. In addition, it is extremely difficult to determine the changes that may occur in the vicinity of the objects, which is the "area coverage - surface water". All modifications within the areas under water could imply changes in the boundaries of cadastral parcels and in the resulting boundaries of the administrative division. The infrastructure for spatial information is based on databases operated by Member States of the European Union. These databases must reflect the reality, so that both the environmental policy run by the European Community and the actions undertaken which affect the environment, were right.

According to the INSPIRE Directive, the hydrographic network is one of the spatial data subjects. It is mentioned as equivalent to the administrative units and cadastral parcels in Appendix I to the Directive on infrastructure for spatial information. Under the Water Framework Directive, the databases of the hydrographic network in Europe are to include the location and boundaries of surface waters.

The aim of this article is to indicate the problem of updating topographic and cadastral databases, as well as administrative division boundaries, combined with the changeability of the environment.

\section{Databaes Created Pursuant to the INSPIRE Directive}

Under the geodetic and cartographic law [1], amended by the law on infrastructure for spatial information [14], for the whole area of the country, a database comprising of collections of spatial data of infrastructure for spatial information is created and executed in the computer system, and it concerns:

- national register of basic geodetic, gravimetric and magnetic control networks;

- land and buildings registration (real estate cadastre);

- surveying records of public utilities;

- state register of boundaries and areas of territorial division units of the country;

- national register of geographical names;

- records of the towns, streets and addresses;

- register of real estate prices and values;

- topographic objects of the detail that ensures the creation of standard cartographic scales of 1:10 000 to 1:100 000, including mapping studies of the digital model of the relief;

- general geographical objects of the detail that ensures the creation of standard cartographic scales of 1:250 000 and smaller, including mapping studies of the digital model of the relief;

- detailed control networks;

- aerial and satellite imagery as well as orthophotos and a digital model of the relief. 
Additionally, for urban areas and built-up rural areas designated for development, databases of topographic objects of the detail that ensures the creation of standard cartographic scales of 1:500 - 1:5000 are created and executed, which are harmonized with the above-mentioned databases.

These collections are designed to provide the ability to generate the following maps:

- cadastral maps in the scales of 1:500, 1:1 000, 1:2 000, 1:5 000;

- master maps in the scales of 1:500, 1:1 000, 1:2 000, 1:5 000;

- topographic maps in the scales of 1:10 000, 1:25 000, 1:50 000, 1:100 000;

- general geographical maps in the scales of 1:250 000, 1:500 000, 1:1 000000.

\section{Surface Waters According to the Polish Law}

The existing water law in Poland [2] divides water into the surface water and groundwater. All, except the water of the territorial sea and internal sea water, are inland waters. Inland surface water is subdivided into flowing and standing water. Their division has been presented in Figure 1 .

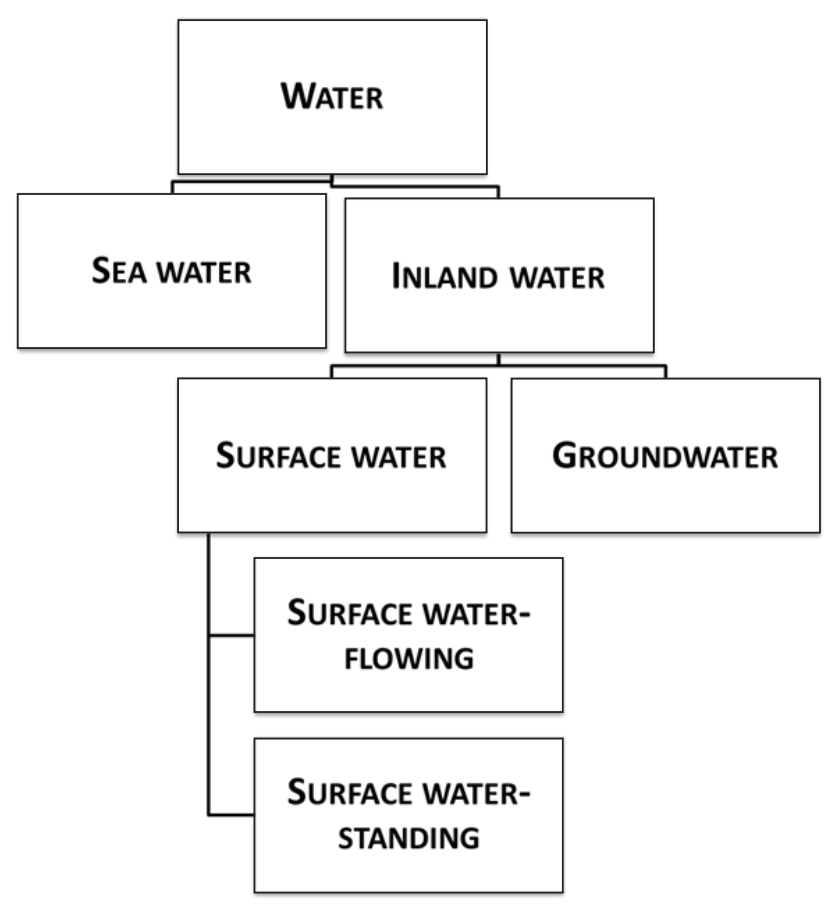

Fig. 1. Division of water according to the water law Source: own study based on [2] 
The information about the various types of water is collected in a database created pursuant to the INSPIRE Directive, and these are the actual data on the characteristics of these objects in the field.

The Polish law contains two slightly differing definitions of various types of waters. The first one results from implementing the executory provision of the geodetic and cartographic law [1], which is the regulation on the land and building registration [13]. The second one - from the water law [2]. The comparison of the explanations of the different documents have been presented in Table 1.

Table 1. Definitions of water types according to the Polish law

\begin{tabular}{|c|c|c|}
\hline Water types & Surveying and cartographic law & Water law \\
\hline $\begin{array}{l}\text { Internal sea } \\
\text { waters }\end{array}$ & $\begin{array}{l}\text { Land under internal sea water is the land } \\
\text { covered with internal sea water, which in- } \\
\text { clude: a part of Neuwarper See and a part } \\
\text { of the Szczecin Lagoon, including the rivers } \\
\text { Swina and Dziwna, as well as Kamieński } \\
\text { Lagoon, located east of the border between } \\
\text { the Republic of Poland and Germany, and } \\
\text { the river Oder between the Szczecin La- } \\
\text { goon and the waters of the port of Szczecin, } \\
\text { a part of the Gulf of Gdansk, closed with } \\
\text { base line running from the point } 54^{\circ} 37^{\prime} 36^{\prime \prime} \\
\text { north latitude and } 18^{\circ} 49^{\prime} 18^{\prime \prime} \text { east longi- } \\
\text { tude (on the Hel Peninsula) to the point } \\
54^{\circ} 22^{\prime} 12^{\prime \prime} \text { latitude N and } 19^{\circ} 21^{\prime} 00^{\prime \prime} \text { east } \\
\text { longitude (on the Vistula Spit) a part of the } \\
\text { Vistula Lagoon, located on the southwest } \\
\text { border between the Republic of Poland } \\
\text { and the Russian Federation on the Lagoon, } \\
\text { port waters defined from the seaward side } \\
\text { by a line joining the outermost permanent } \\
\text { harbor devices, forming an integral part of } \\
\text { the port system }\end{array}$ & \multirow[t]{3}{*}{$\begin{array}{l}\text { Land covered by inland surface waters } \\
\text { and sea internal waters means the land } \\
\text { forming beds and banks of natural wa- } \\
\text { tercourses, lakes and other natural water } \\
\text { bodies, within the limits of the shoreline, } \\
\text { and the land included in the artificial wa- } \\
\text { ter basins, barrages and dammed lakes, } \\
\text { being land covered with surface water be- } \\
\text { fore constructing damming devices. } \\
\text { The bank line of the natural water courses, } \\
\text { lakes and other natural bodies of water is } \\
\text { the edge of the shore or a permanent line } \\
\text { of grass sward, or a line which is deter- } \\
\text { mined by the average water level of a pe- } \\
\text { riod of at least the last } 10 \text { years }\end{array}$} \\
\hline $\begin{array}{l}\text { Flowing } \\
\text { surface water }\end{array}$ & $\begin{array}{l}\text { The land under flowing surface water in- } \\
\text { cludes the land under the water flowing } \\
\text { in rivers, mountain streams, canals and } \\
\text { other watercourses, of constant or peri- } \\
\text { odic flows, and the springs from which } \\
\text { the streams originate, as well as the land } \\
\text { under water located in the artificial lakes } \\
\text { and basins, from which the streams flow } \\
\text { out or to which they flow in }\end{array}$ & \\
\hline $\begin{array}{l}\text { Standing } \\
\text { surface water }\end{array}$ & $\begin{array}{l}\text { The land under standing surface water in- } \\
\text { cludes the land under water in lakes and } \\
\text { basins other than those specified above }\end{array}$ & \\
\hline
\end{tabular}


There is a clear one major difference between these definitions. The water law specifies the scope of water by defining it with shorelines. Geodetic and cartographic law does not specify the exact location of the contour of agricultural land, it only indicates its approximate extent by describing what types of water the land is covered by.

\section{Surface Water as Database Objects}

Internal sea waters and surface waters are introduced as database objects of topographic objects (BDOT500). In addition, with their location, the contours of the land covered by water and cadastral plots boundaries, stored in a registration database (EGiB), are strongly connected. From their geometry, reference to a database of the state record of the boundaries and territorial division units (PRG) may derive.

Elements of all these bases constitute the contents of the master map. The printout should contain the elements which derive from BDOT500, EGiB and PRG, respectively, according to Table 2 .

Table 2. Selected objects constituting the content of the master map

\begin{tabular}{|c|c|}
\hline Object & $\begin{array}{c}\text { Database used for acquiring } \\
\text { the object }\end{array}$ \\
\hline State & \multirow{4}{*}{ PRG } \\
\hline Province & \\
\hline District & \\
\hline Commune & \\
\hline Cadastral unit & \multirow{7}{*}{ EGiB } \\
\hline Registration precinct & \\
\hline Record parcel & \\
\hline Border marker & \\
\hline Land under internal sea water & \\
\hline Land under flowing surface water & \\
\hline Land under standing surface water & \\
\hline Sea water & \multirow{3}{*}{ BDOT500 } \\
\hline Flowing water & \\
\hline Standing water & \\
\hline
\end{tabular}


It is important that data from particular databases are consistent and that the report resulting from them in the hard copy of the master map does not contain contradictory information.

The proposed regulation on the geodetic utilities database, topographic objects database and the master map [12] introduces a classification of the objects BDOT500 at three levels of detail:

1) the first level - containing categories of classes of objects,

2) the second level - containing classes of objects,

3) the third level - containing objects.

For these levels of classification, a simple coding system was adopted. The classification of the objects for the class "area coverage - surface water" along with the code names have been contained in Table 3.

Table 3. Classification of the BDOT500 objects

\begin{tabular}{|c|c|c|c|c|c|}
\hline \multicolumn{2}{|c|}{ Level 1} & \multicolumn{2}{|c|}{ Level 2} & \multicolumn{2}{|c|}{ Level 3} \\
\hline CODE & $\begin{array}{c}\text { the name } \\
\text { of categories } \\
\text { of classes of } \\
\text { objects }\end{array}$ & CODE & $\begin{array}{l}\text { the name } \\
\text { of classes of } \\
\text { objects }\end{array}$ & CODE & object name \\
\hline \multirow{3}{*}{ pT } & \multirow{3}{*}{ area coverage } & \multirow{3}{*}{ PTWP } & \multirow{3}{*}{ surface water } & PTWP01 & sea water \\
\hline & & & & PTWP02 & flowing water \\
\hline & & & & PTWP03 & standing water \\
\hline
\end{tabular}

Source: own study based on [12]

The objects in the registration database (Tab. 4) and the database of state register of boundaries (Tab. 5) have been defined similarly.

Table 4. Classification of the EGiB objects

\begin{tabular}{||c|c|c|c|c|c||}
\hline \hline \multicolumn{2}{|c|}{ level 1 } & \multicolumn{2}{c|}{ Level 2 } & \multicolumn{2}{c||}{ Level 3 } \\
\hline \multirow{2}{*}{ CODE } & $\begin{array}{c}\text { the name } \\
\text { of categories } \\
\text { of classes of } \\
\text { objects }\end{array}$ & CODE & CODE & $\begin{array}{c}\text { the name of } \\
\text { categories } \\
\text { of classes of } \\
\text { objects }\end{array}$ & CODE \\
\hline \hline \multirow{2}{*}{ pA } & $\begin{array}{c}\text { administrative } \\
\text { division }\end{array}$ & PAPE & $\begin{array}{c}\text { registration } \\
\text { division }\end{array}$ & PAPE02 & $\begin{array}{c}\text { registration } \\
\text { precinct }\end{array}$ \\
\cline { 4 - 6 } & & & PAPE03 & record parcel \\
\hline
\end{tabular}

Source: own study based on [12] 
Table 5. Classification of the PRG objects

\begin{tabular}{|c|c|c|c|c|c|}
\hline \multicolumn{2}{|c|}{ level 1} & \multicolumn{2}{|c|}{ Level 2} & \multicolumn{2}{|c|}{ Level 3} \\
\hline CODE & $\begin{array}{l}\text { the name } \\
\text { of categories } \\
\text { of classes of } \\
\text { objects }\end{array}$ & CODE & CODE & $\begin{array}{l}\text { the name } \\
\text { of categories } \\
\text { of classes of } \\
\text { objects }\end{array}$ & CODE \\
\hline \multirow{4}{*}{ PA } & \multirow{4}{*}{$\begin{array}{l}\text { administrative } \\
\text { division }\end{array}$} & \multirow{4}{*}{ PAPT } & \multirow{4}{*}{$\begin{array}{l}\text { territorial } \\
\text { division }\end{array}$} & РАРT01 & state \\
\hline & & & & РАРТ02 & province \\
\hline & & & & РАРТ03 & district \\
\hline & & & & РАРТ04 & commune \\
\hline
\end{tabular}

Source: own study based on [12]

Geometric representation of the objects of the class PTWP is the area, whose boundaries are defined, respectively:

- according to the EGiB database, for the object of the PTWP01 class;

- according to the EGiB database, in the case of the location of the shoreline in the distance of no more than $0.50 \mathrm{~m}$ from the boundary of the record parcel or agricultural land, for the objects of the PTWP02, PTWP03 classes.

Objects of the state register of the boundaries are hierarchically set up from the objects of the registration database. This means that they are created based on the principle "from the particular to the general," according to the scheme: record parcel - registration precinct - cadastral unit (commune) - district - province - state.

Since the master map is a report of the databases created pursuant to the INSPIRE Directive, the cartographic visualization of objects representing its content is done automatically [12] using cartographic symbols (Tab. 6).

Table 6. Cartographic visualization of the master map objects

\begin{tabular}{|c|c|}
\hline Object name & Cartographic symbol \\
\hline state & Rzeczpospolita Polska \\
\hline province & woj. mazowieckie \\
\hline district & pow. zamojski \\
\hline commune & gm. Pisz \\
\hline unit & Nowa Huta \\
\hline precinct & 0012 \\
\hline parcel & $4 / 1$ \\
\hline
\end{tabular}


Table 6 cont.

\begin{tabular}{|c|c|}
\hline Object name & Cartographic symbol \\
\hline \hline agricultural land & \\
\hline sea water & Zatoka Gdańska \\
\hline flowing water & \\
\hline standing water & \\
\hline
\end{tabular}

Source: own study based on [12]

It is important that a multitude of symbols did not lead to vagueness of the report generated from databases. Therefore, the relationships between particular databases should be examined in the first place.

\section{Example of the Relations of the Existing Collections}

An example of a place where there are relations between all three listed databases (BDOT500, EGiB, PRG) is a fragment of the Vistula riverbed located to the west of Krakow (Poland, Małopolska Province). Its location is shown in Figure 2.

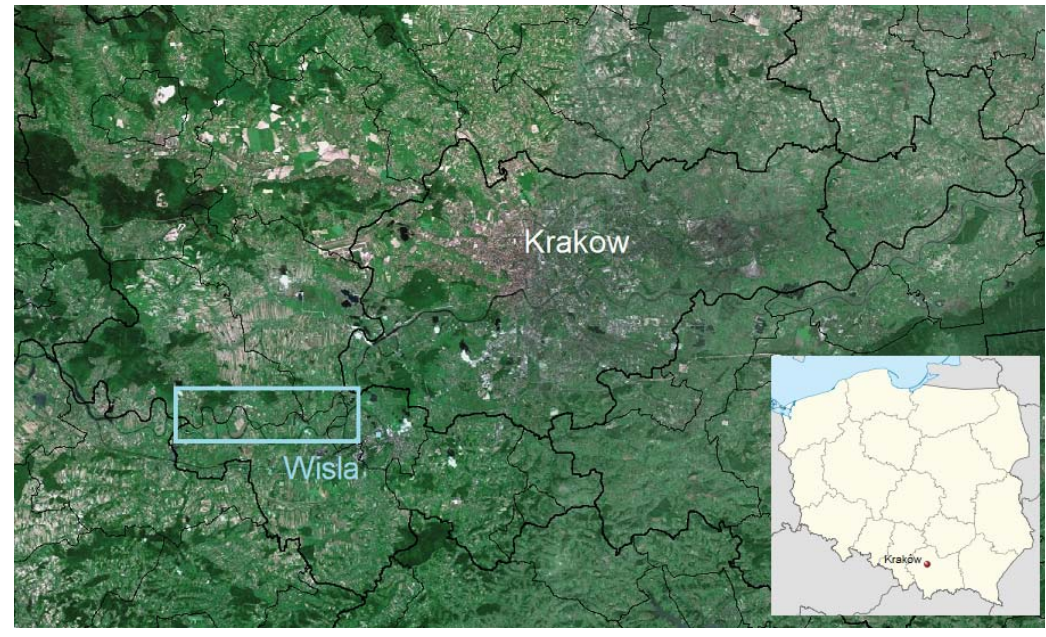

Fig. 2. Location of the analyzed fragment of the Vistula River Source: own study based on [15] 
Since it is the administrative boundary between the three minor units of territorial division in Poland: Czernichów commune, Liszki commune and Skawina commune (Krakow district, Małopolska region). The data about the middle of the river, which constitutes the boundary, are located in the state register of boundaries. The printout from the PRG's base has been contained in Figure 3.

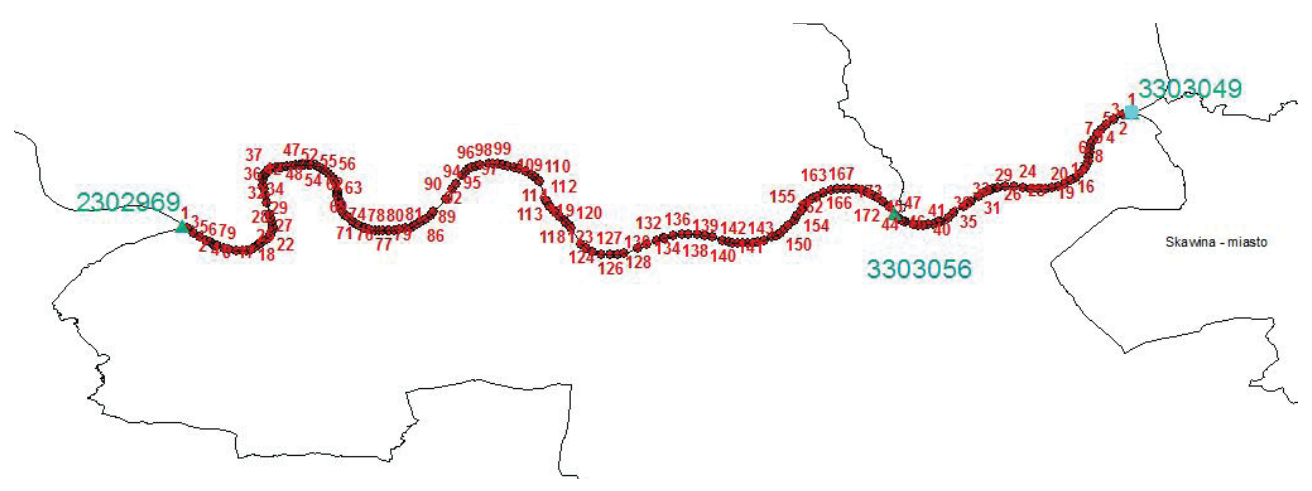

Fig. 3. State register of boundaries

Source: PRG

This boundary should coincide with the registration boundaries from the database EGiB. This relation has been shown in Figure 4, where against the orthophotos, registration boundaries (red colour) and administrative boundaries (yellow) have been marked.

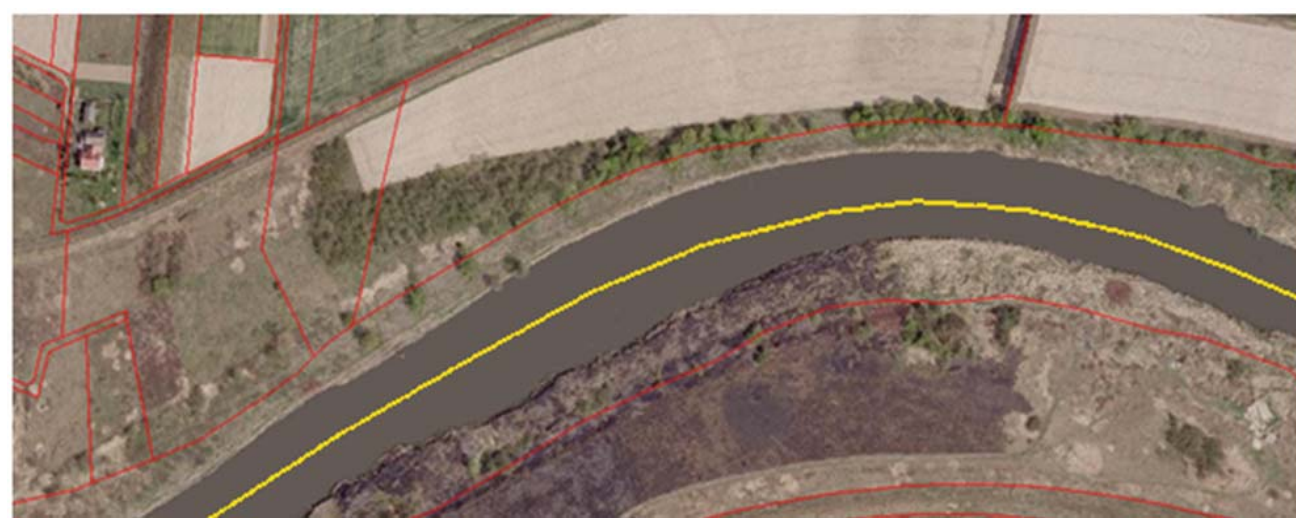

Fig. 4. Real Estate Cadastre

Source: own study based on [15] 
After marking the topographic database content on the orthophotomap, it is clear that it was created based on aerial photographs. The image of the river in the base coincides with the actual riverbed (Fig. 5).

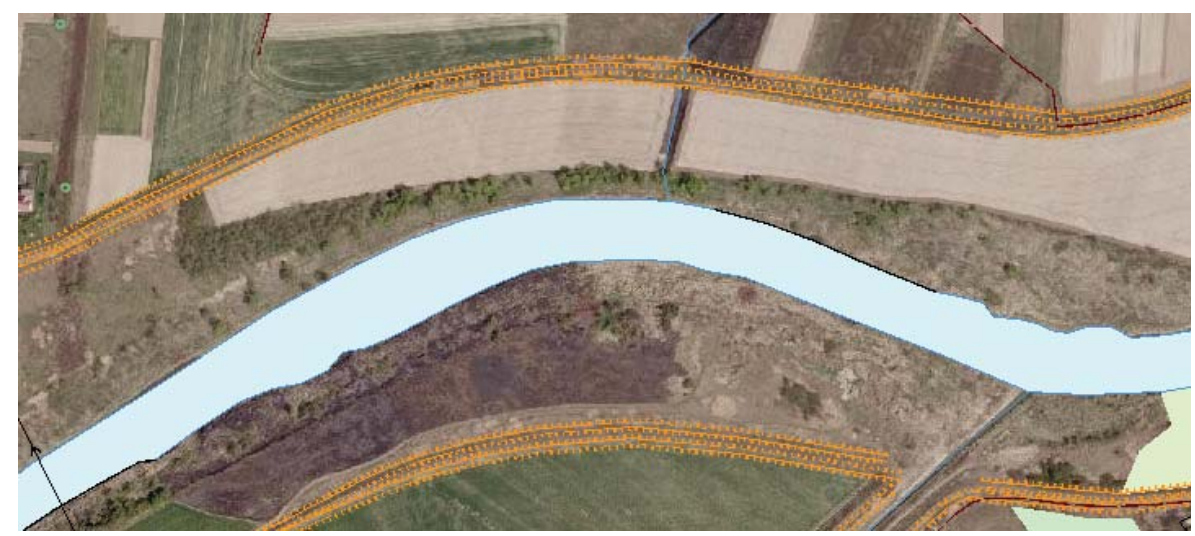

Fig. 5. Topographic database

Source: own study based on [15]

It seems to be obvious that it is necessary to validate the correctness of the registration and administrative boundaries in the vicinity of surface waters.

Such control was carried out for the discussed Vistula section [3]. As a result, it was found that it was necessary to update data in the created databases in such a way as to achieve their consistency.

Figure 6 presents the situation in which the administrative boundary generated (green line) as the middle of a riverbed can be shifted by almost 25 meters, because riverbank lines were shifted as well.

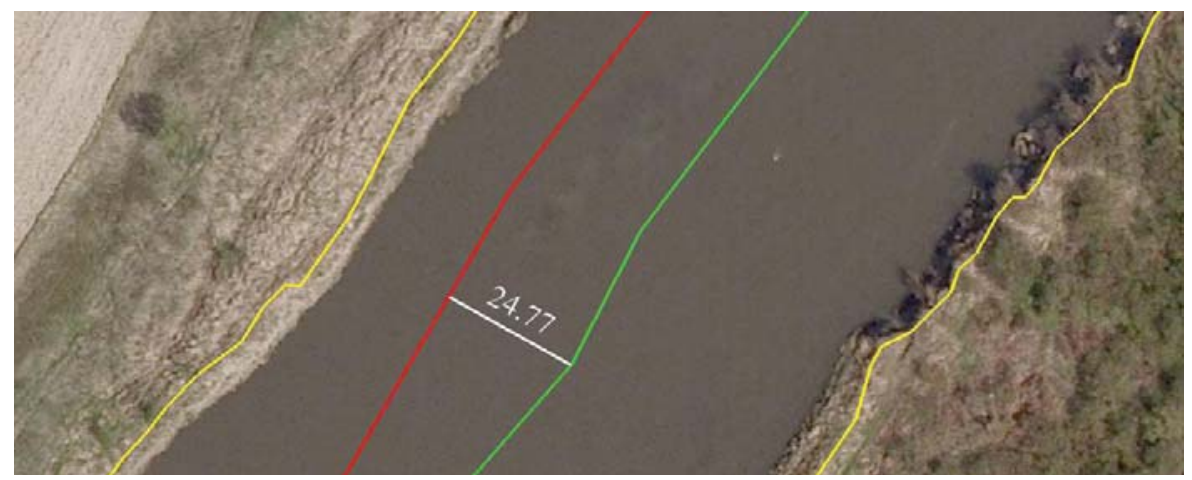

Fig. 6. Changing the administrative boundary

Source: [3] 
The situation shown in Figure 7 is the result of crossing the registration boundaries by flowing water, as a result of which changes to the EGiB database should occur.

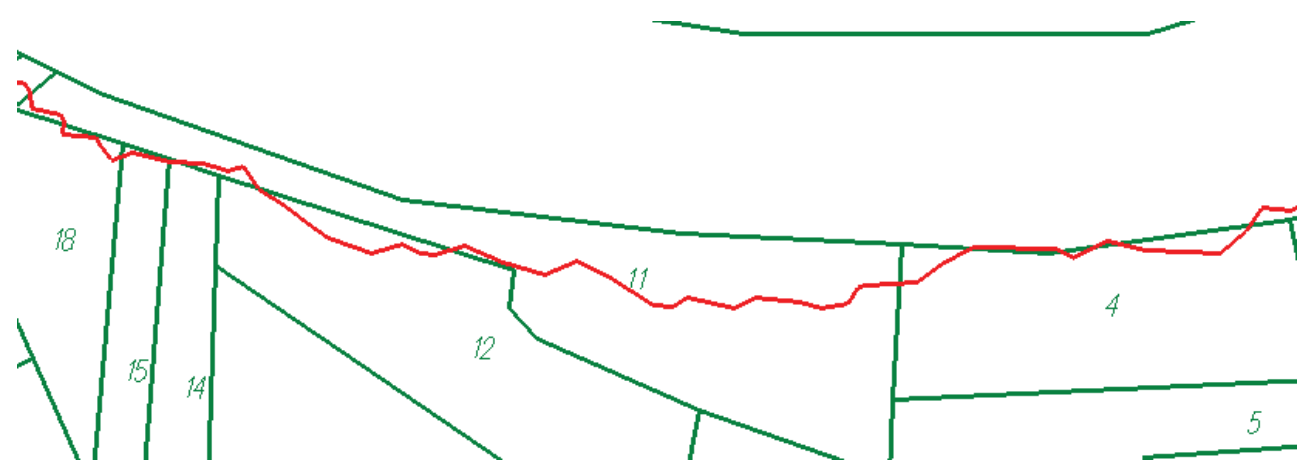

Fig. 7. Shifting the riverbank (red line) against the cadastral map

Source: [3]

\section{Conclusion}

In conclusion, the authors would like to point out that:

1. Periodic inspections of the course of shorelines are necessary in order to update the databases created pursuant to the INSPIRE Directive. It was also taken into account by the legislator. It has been decided in the draft version of new order concerning ground and building cadastre [6], that until establishing the shorelines of natural waters, the shorelines survey results should be recorded in the cadastral database (EGiB).

2. The cadastral database (EGiB), the database of the state register of boundaries (PRG) and the topographic database (BDOT500) should be updated at the same time, based on the same data. This is closely related to the provisions of the Polish law, according to which their components should not be mutually exclusive, as they are the contents of one map - the master map.

\section{References}

[1] Ustawa z dnia 17 maja 1989 r. - Prawo geodezyjne i kartograficzne. Dz. U. z 1989 r. Nr 30, poz. 163 z późn. zm. [Act of 17 May 1989 - Geodesic and Cartographic Law. Journal of Laws of 1989, No. 30, item 163, as amended].

[2] Ustawa z dnia 18 lipca 2001 r. - Prawo wodne. Dz. U. z 2001 r. Nr 115, poz. 1229 z późn. zm. [Act of 18 July 2001 - Water Law. Journal of Laws of 2001, No. 115 , item 1229 , as amended]. 
[3] Bieda A.: Weryfikacja granic administracyjnych prowadzonych wzdłuż rzek $w$ aspekcie aktualizacji kataster. Akademia Górniczo-Hutnicza, 2011 [Ph.D. thesis, unpublished].

[4] Bielecka E.: Określenie zasobu podstawowego infrastruktury informacji przestrzennej w Polsce. Roczniki Geomatyki, t. VIII, z. 8, 2010, pp. 31-40.

[5] Directive 2007/2/EC of the European Parliament and of the Council of 14 March 2007 Establishing an Infrastructure for Spatial Information in the European Community (INSPIRE).

[6] Projekt rozporzadzenia Ministra Administracji i Cyfryzacji zmieniajacy rozporządzenie w sprawie ewidencji gruntów i budynków [on-line:] http://www. gugik.gov.pl/bip/projekty-aktow-prawnych/projekt-rozporzadzenia-ministra-administracji-i-cyfryzacji-zmieniajacy-rozporzadzenie-w-sprawieewidencji-gruntow-i-budynkow.

[7] Gaździcki J.: Problematyka transpozycji dyrektywy INSPIRE do prawa polskiego. Przegląd Geodezyjny, r. 79, nr 5, 2007, pp. 14-17.

[8] Gaździcki J.: Implementacja Dyrektywy INSPIRE w Polsce - stan aktualny, problemy i wyzwania. Roczniki Geomatyki, t. IV, z, 3, 2008, pp. 21-30.

[9] Lewandowicz L.: Harmonizacja zbiorów publicznych - problemy z nazwami istatusami jednostek administracyjnych. Archiwum Fotogrametrii, Kartografii i Teledetekcji, vol. 23, 2012, pp. 219-228.

[10] Michalak J.: Transformacja polskich danych przestrzennych do modeli INSPIRE. Roczniki Geomatyki, t. VIII, z. 4, 2010, pp. 27-51.

[11] Rozporządzenie Rady Ministrów z dnia 21 lutego 2012 r. w sprawie państwowego rejestru granic i powierzchni jednostek podziałów terytorialnych kraju. Dz. U. z 2012 r., poz. 199 [Regulation of the Council of Ministers of 21 February 2012 on the state register of boundaries and territorial division units of the country. Journal of Laws of 2012, item 199].

[12] Rozporzadzenie Ministra Administracji i Cyfryzacji z dnia 12 lutego 2013 r. w sprawie bazy danych geodezyjnej ewidencji sieci uzbrojenia terenu, bazy danych obiektów topograficznych oraz mapy zasadniczej. Dz. U. z 2013 r. Nr 0, poz. 383 [Regulation of the Minister of Administration and Digitalization of 12 February 2013 on the geodetic utilities database network, topographic objects database and the master map. Journal of Laws of 2012, No. 0, item 383].

[13] Rozporzadzenie Ministra Rozwoju Regionalnego i Budownictwa z dnia 29 marca 2001 r. w sprawie ewidencji gruntów i budynków. Dz. U. z 2001 r. Nr 38, poz. 454 [Regulation of the Minister of Regional Development and Construction of 29 March 2001 on the registration of land and buildings. Journal of Laws of 2001, No. 38, item 454].

[14] Ustawa z dnia 4 marca 2010 r. o infrastrukturze informacji przestrzennej. Dz. U. z 2010 r. Nr. 76, poz. 489 [The Act of 4 March 2010 on the infrastructure for spatial information. Journal of Laws of 2010, No. 76, item 489].

[15] www.geoportal.gov.pl. 